\title{
PROLIFERAÇÃO DAS \#HASHTAGS: LÓGICA DA CIÊNCIA, DISCURSO E MOVIMENTOS SOCIAIS CONTEMPORÂNEOS
}

Fernanda Costa-Moura

Fernanda Costa-Moura

Professora do

Programa de

Pós-graduação

em Teoria

Psicanalítica da

UFRJ; psicanalista, membro do

Tempo Freudiano

Associação

Psicanalítica.
RESUMO: Considerando a eclosão das manifestações acontecidas em junho de 2013 no Brasil, relacionada à comunicação corrente nas chamadas 'redes sociais', o artigo aborda a problematização introduzida pela operação científica para a sustentação do lugar do sujeito no campo discursivo. Examinam-se alguns dos novos expedientes de encadeamento do laço social disponibilizados no meio eletrônico-digital, para discutir os modos de representação que nossa contemporaneidade atravessada pela ciência oferece à subjetividade.

Palavras-chave: Psicanálise, sujeito, ciência, discurso, movimentos sociais contemporâneos.

ABSTRACT: Proliferation of the \#hashtags: logic of science, discourse and contemporary social movements. Considering that the outbreaks of the Demonstrations that arouse in June 2013 in Brazil are very closely related to the type of communication that is currently found in the social-media platforms, the article intends to discuss the problems that scientific operation introduces to sustain the role of the subject in the field of the discourse. It examines some of the new discourse starters and social relations arrangements available in digital media, debating the forms and possibilities of representation that contemporary society sponsored by science offers to subjectivity.

Keywords: Psychoanalysis, subject, science, discourse, contemporary social movements. 
E m junho de 2013 o Brasil testemunhou, admirado, a irrupção extraordinária de uma das maiores mobilizações de massas na história recente do país. Sem que ninguém pudesse prever, sem líderes identificados, sem partidos nem sindicatos em sua organização, a princípio sem apoio da mídia, espontaneamente, foram tomando os espaços públicos, uns poucos de início, aos quais se juntaram centenas, que se tornaram milhares e conseguiram o apoio de milhões. Sem chegar a se definir mais precisamente contra, ou a favor de que, o movimento se espalhou em rede e foi se transformando em indignação manifestada por meio da impressionante ocupação das ruas por multidões expressivas em mais de 300 (!) grandes, médias e mesmo pequenas cidades do país, rebentando até mesmo em municípios periféricos — como São Gonçalo, Itaboraí ou Nova Iguaçu, no caso do Rio de Janeiro - , com a maioria da população situada nas classes populares e sem história marcante de maior participação política. ${ }^{1}$

A causa desencadeante era aparentemente diminuta - literalmente expressa em centavos, ${ }^{2}$ não fosse seu valor de “gota d’água” (no fatídico dia 20/6/2013, quando o país parou, um cartaz na Cinelândia dizia: "descobrimos o preço da gota d'água: 20 centavos”). Ou antes, digamos com a rede, seu potencial de viralização. Vale dizer: sua capacidade enigmática de atrair, mobilizar e congregar milhares de indivíduos — ou de perfis (como veremos adiante).

As manifestações no Brasil seguiram justamente o processo de "propagação viral" de protestos que aconteceram em outros lugares do mundo, como os levantes contra as ditaduras do Egito, Tunísia e Líbia que configuraram a chamada Primavera Árabe e o Occupy Wall Street nos Estados Unidos (para ficar apenas nas duas mais notáveis, entre as várias irrupções ocorridas nos últimos três ou quatro anos). Aqui também os protestos iniciaram nas redes sociais da internet que são espaços que escapam à dominância dos governos e empresas que monopolizam os canais de comunicação (CASTELLS, 2012). E "se tornam um movimento ao ocupar o espaço urbano” (idem, p.160). Mobilizando os jovens, especialmente, depois de mais de uma década de relativa retirada da vida política, a estarem presentes ("O povo acordou, o povo decidiu: ou para a roubalheira, ou paramos o Brasil”), a reivindicar ("Da copa, eu abro mão, queremos é dinheiro pra saúde e educação") e tomar em mãos o movimento ("O povo unido protesta sem partido”).

\footnotetext{
${ }^{1}$ De acordo com registros na Wikipédia, todos os 27 estados brasileiros, e suas respectivas capitais, tiveram algum tipo de manifestação e várias cidades; e ao menos 18 países diferentes também apoiaram a causa. O auge da mobilização se deu no dia 20 de junho com cerca de 1,5 milhão de pessoas nas ruas. Ao todo foram 13 dias de protestos, em cerca de 300 cidades, com média de 540 mil participantes nos cinco dias de maior aderência das cidades. 2 Embora não tenham se reduzido a esta reivindicação, os protestos começaram pela contestação do aumento de $\mathrm{R} \$ 0,20$ no preço das tarifas dos ônibus urbanos.
} 
Acontecimentos como este deixam muito a debater e um rol de questões que é importante tentar não reduzir imediatamente ao que já sabemos. Primeiro, porque como os movimentos urbanos envolvidos nestes atos políticos não se esgotaram em obter concessões de curto prazo, eles parecem ser decorrência de um desconforto e descontentamento maior (ZIZEK, 2011, 2013), que não pôde se traduzir numa pauta de reivindicações objetivas, em nenhum lugar onde eclodiu e, por isso mesmo, desafia governos e governantes (ALI, 2011). Ao mesmo tempo, nenhum destes movimentos deixou de mobilizar questões econômicas e político-ideológicas, de maior ou menor radicalidade, que incluíram desde reivindicações pela democracia (Tunísia, Egito, Turquia), até questionamentos e exigências de reinvenção da própria democracia representativa multipartidária atual, em função da inoperância deste sistema para combater os excessos do capitalismo (Espanha, Grécia, EUA).

Trata-se, pois, de uma situação complexa e sobredeterminada. Evidentemente se por estrutura ela interpela, e arrisca mesmo romper com a mediação política, não se equipara por inteiro a um esvaziamento da política. Ao contrário, pode-se dizer que resta daí uma "demanda de política” (SAFATLE, 2011); o clamor por uma liderança que indique como seguir adiante após esta primeira etapa, e que demonstre como dar os próximos passos — em que direção? —, sem recair nas alternativas totalitárias. Por outro lado, na contraface desse âmbito mais amplo da economia e dos governos, surge uma nova sensibilidade política. Uma nova forma de participação que transforma a insatisfação em acontecimento — através de ações pontuais, que apostam não nos ideais, nos fins, mas numa efetividade dos meios, da presença real.

As variáveis em jogo são inúmeras e vão desde o estopim que dá início à expansão dos movimentos, até a resposta dos governos, a atuação da polícia diante dos protestos violentos e não violentos, as novas formas de mídia e seu embate com a imprensa dita tradicional, e por fim a grande questão que paira: como chegar a escutar — e sobretudo dar consequência — ao que pode nos dizer essa massa contingente de jovens que cresceu de súbito nas manifestações de rua?

Sem pretender abordar diretamente toda a extensão, a força e a complexidade das manifestações que tomaram nosso país e o mundo nos últimos anos, este trabalho pretende delimitar alguns elementos que permitem estabelecer uma vinculação destes movimentos de massa com as relações discursivas surgidas em algum ponto indiscernível entre o aparecimento de novas tecnologias e as operações de formalização da linguagem que estão na base da operação da ciência. Não se trata de chegar a um saldo, extrair uma lição, visto que a história mal começou, e sequer começou em junho (nem aqui). Não se sabe se, e de que modo, a forma de fazer política será transformada pela irrupção destes "movimentos articulados em rede" (CASTELLS, 2012, p.157 ss). Mas considerando que a onda 
recente de manifestações que varreu o país foi propagada por uma espécie de boca a boca (ou tweet a tweet) eletrônico — com mensagens replicadas a milhares de emissores - buscamos distinguir algumas práticas de convocação, de endereçamento e registro que constituem o discurso eletrônico-digital difundido entre os jovens. E mais especificamente, assinalar seu aspecto discursivo, sua função de encadeamento de um laço social cujo paradigma é fornecido por expedientes como 'evento', 'perfil', e '\#hashtag', como veremos a seguir.

Como se trata de elementos originados no processo de formalização da linguagem que está na base da ciência moderna, sua força de mobilização coloca em questão os modos de representação que nossa contemporaneidade atravessada pela ciência oferece à subjetividade.

\section{ELES NÃO USAM CARTAZES}

Em numerosas cidades de todo o mundo foram, sobretudo, os jovens — sem contar tanto com uma formação política, mas com muita raiva e indignação que tomaram as ruas, as praças, viadutos e muros, que invadiram prédios, e viraram carros, que apanharam e combateram a polícia, às vezes com pedras e bombas, mas, em sua maioria, armados apenas de vinagre e camisetas enroladas nos rostos. Com reivindicações particulares em cada região e formas de luta muito semelhantes — arrojadas, insólitas, inovadoras — a onda de mobilização tomou a dimensão de um protesto global. A tal ponto que não se pode dizer exatamente o que cada um dos movimentos afirma ou reivindica. Nem precisa - uma vez que a presença maciça da população nas ruas é o acontecimento em si ("Abaixo tudo” — dizia o cartaz, na Cinelândia/RJ).

De qualquer modo, a cada dia surgem ocupações, rolezinhos, e vários tipos de aglomerações instantâneas que recusam o espaço institucional tradicional e se articulam por meio de redes de comunicação alternativas. A estratégia consiste principalmente em tomar um espaço público — central ou periférico (praças, esplanadas, cruzamentos, shoppings) - e com a simples presença dos corpos ali, convertê-lo em espaço político. Quando todos os outros canais de expressão estão bloqueados - pelo poder das políticas de governo, do dinheiro e do funcionamento social instituído - esse simples comparecimento no espaço de convivência coletiva (real ou virtual) torna-se uma forma efetiva de oposição e intervenção.

Apoiando-se nesta tática, herdada das lutas que se desenvolveram em Wall Street, em Nova York, na praça Tahrir, no Cairo, Puerta del Sol, em Madri, praça Syntagma, em Atenas, Taksim, em Istambul e, recentemente, como se viu, nas aglomerações impressionantes que aconteceram nas avenidas de São Paulo, no Centro e na periferia do Rio, e na Esplanada do Congresso em Brasília, a onda 
alastra-se de cidade em cidade, reavivada em pequenos e grandes agrupamentos, que fazem apostar numa potência dos movimentos de resistir e renovar a própria falta de retórica.

Assim, os manifestantes mostram outro funcionamento da cidade - como suporte, como campo de combate, e ao mesmo tempo região de uma interdependência que eles anunciam e usam em sua intervenção. Sabendo que o bloqueio de um cruzamento importante compromete toda a circulação, os manifestantes usam "a cidade como arma para sua própria retomada” (MOVIMENTO PASSE LIVRE/SP, 2013, p.16). Pelo que gera de transtorno na organização usual dos territórios, a gestão dos fluxos do espaço urbano expressa revolta, indignação e protesto, em sua radicalidade. Fazendo ressoar o problema maior do alheamento em relação aos processos políticos, econômicos e outros que determinam a vida social, cada manifestação ou ocupação é ao mesmo tempo local e global. Nas palavras do Movimento Passe Livre, "A organização descentralizada da luta é um ensaio para outra organização do transporte, da cidade e de toda a sociedade" (MPL/SP, 2013, p.17).

Falou-se bastante das manifestações que ocorreram no Brasil como um grito, mas o que diz esse grito, o que diz 'a voz das ruas', como nomeou a presidente Dilma Rousseff, é mais difícil de isolar. Num dado momento, em meio à onda de manifestações que se sucediam na cobertura exibida ao vivo, um repórter atônito com a força indescritível do levante que acontecia naquele final de tarde na comunidade popular do Alemão (no Centro do Rio), narrava a movimentação de cerca de uma centena de homens, mulheres e crianças, que passavam em frente à câmera, ostensivamente encapuzados. Diante daquele desfile, tão contundente, o repórter comentou “eles não usam cartazes...”.

De fato, essa foi mesmo uma das surpresas trazidas pelas novas maneiras de participação que surgiram: onde estava o discurso? As bandeiras? O carro de som com as palavras de ordem? Onde estavam os líderes? Quem liderava? Aproveitando, e ampliando, o assombro do repórter, talvez se possa dizer que há, aí mesmo, uma divisa: "eles não usam cartazes". Ou, pelo menos, em sua recusa da luta pelo poder, abominação dos partidos e demais entidades de representação política de qualquer tendência, aqueles rostos cobertos retiram os cartazes do discurso reivindicativo. Às vezes em prol de um discurso perturbador que as câmeras registraram avidamente ("Tem tanta coisa errada que não cabe em um cartaz", dizia um cartaz); enquanto o essencial - é unanimidade dizer com Malini (2013), Sakamoto (2013), Zizek (2012), Castells (2012), entre outros - , se transmite através de tags on-line, utilizadas em larga escala nas

\footnotetext{
${ }^{3}$ Agradeço à Simone Gryner, que chamou minha atenção quanto a isso e me indicou a reportagem mencionada.
} 
redes sociais, como facebook, tweeter e Instagram. Criando um protesto global que mobiliza apoiadores em várias partes do mundo e inspira toda uma maquinaria internacional de imprensa e comunicação alternativas à mídia centralizada nos interesses político-econômicos usuais.

Em lugar de cartazes, portanto, \#hashtags. Multiplicação dos likes - que se disseminam de forma virtualmente infinita: \#passelivre \#vemprarua \#ogiganteacordou \#nãovaitercopa. "Diferentes movimentos dentro do movimento" (MALINI, 2013).

\section{9\%}

Mas o que implica esse elemento novo do discurso que não cabe no registro da reivindicação, nem da palavra de ordem, e configura um domínio próprio, outro: o streamming incessante das \#hashtags? Protestos iniciados na rede e inteiramente articulados através das novas tecnologias de comunicação evidenciam, a cada dia, que estas tecnologias não são apenas ferramentas de descrição do mundo. Elas são formas novas de criação e desconstrução da realidade. Quando alguém atua por meio dessas chamadas "redes sociais" não está simplesmente reportando algo, mas está também gerando, engendrando, transformando o real - alterando, de forma inédita, o ativismo político e social e os modos de participação no discurso.

Em 13 de julho de 2011, a revista canadense de crítica cultural Adbusters postou no seu blog a convocação: \# occupywallstreet. A revista convocava para "um momento Tahrir” inspirado na ocupação da Praça Tahrir e nas acampadas da Espanha. Um "movimento de resistência, sem liderança, com pessoas de muitas cores, gêneros e opiniões políticas"; cuja reivindicação única era: "poder a pessoas reais para criar uma mudança real” (http://web.occupywallst.org). "A beleza dessa nova formula é sua simplicidade: falamos uns com os outros em encontros físicos e assembleias populares, saímos e tomamos uma praça de singular importância simbólica e nos arriscamos para fazer com que isso aconteça”. No dia marcado, 17 de setembro, aniversário da Constituição americana, o Parque Zuccotti, em Nova York, foi se enchendo de gente com uma demanda simples (separar a política do capital e do poder), irrealista (restituir a democracia ao povo), mas enunciada numa pluralidade de vozes. O lindo pôster que anunciava o evento mostrava uma bailarina diáfana se equilibrando em cima do "touro de Wall Street” (o “charging bull” enorme escultura de bronze representando um touro em posição de ataque que se tornou símbolo do distrito financeiro de Manhattan). E suas placas traziam uma expressão nova: "Nós somos os 99\%".

We are the 99\% era originalmente o nome de uma página do blog Tumblr criado em final de agosto por um ativista do movimento Anonymous conhecido 
(simplesmente) como “Chris". A frase remeteria em princípio à notícia divulgada pela ONG britânica, Oxfam International, de que 1\% da população possui e controla 46\% da riqueza do planeta. Mas \#WeAreThe99\% foi muito mais que uma frase e o título de um blog. Foi um choque de realidade. Adotada como a hashtag do movimento Occupy Wall Street (OWS), se multiplicou em textos, protestos e notícias estarrecedoras sobre a concentração de renda que começaram a brotar em toda parte. \#NosSomosOs99\%que vivem com 54\% da riqueza mundial. \#NosSomosOs99\%que não vão mais tolerar a ganância e a corrupção de 1\%. Não se tratava de pertencer ao 1\%, e sim de chegar aos 99\%: "Queremos ver uma assembleia em todo quintal, em cada esquina, porque nós não precisamos de Wall Street e não precisamos de políticos para construir uma sociedade melhor" (occupywallst.org). Num mundo conectado pela internet, pode-se ter acesso imediato a lutas e projetos que deixaram marcas de uma possibilidade de mudança real — como meio de instaurar uma democracia real (\#DemocraciaRealYa, como pediam os Indignados da Espanha).

Ora, nenhum desafio à autoridade do Estado fica sem resposta. A ocupação iniciada em 17/9 no Zucotti Park foi seguida por um sem número de prisões efetuadas pela polícia sob diversos pretextos. No caso das revoluções árabes e no Egito, houve repressão aberta, censura à mídia e bloqueio da internet. Mas a repressão não pode sustentar-se contra um movimento de massa articulado pelas novas tecnologias de comunicação em rede. Quanto mais a polícia recorria à repressão mais as imagens das ações policiais postadas no YouTube mobilizaram manifestantes. A resistência veio de muitas áreas, da engenhosidade dos manifestantes primeiramente, mas sobretudo da vigilância da própria comunidade global da web: hackers, redes de militantes como o Anonymous e outras, engajados na defesa dos direitos humanos, fanáticos por tecnologia e pessoas de todo tipo para quem a internet se tornou um direito fundamental (e um modo de vida). Quando, meses depois, a polícia nova-iorquina desocupou à força o Zucotti, o Occupy Wall Street, não tinha mudado o mundo, mas problematizara irreversivelmente a agenda política e econômica da civilização — pela simples e maciça difusão mundial da ideia de que é inaceitável que a humanidade se divida entre $99 \%$ e $1 \%$.

O OWS dá bem a medida de como a catarse política protagonizada pelos movimentos populares que eclodiram e se espalharam por várias regiões do mundo colocou em xeque o modo de vida contemporâneo global. E juntamente com isto, também o campo discursivo que esteia a vida social. Com imagens e notícias espalhando-se pela internet, a ocupação (iniciada em 17/9) começou de modo espontâneo em muitas outras cidades do mundo, nos primeiros dias de outubro, atingindo mais de mil cidades, em todos os 50 estados, só nos EUA - e até o gramado em frente à Casa Branca - com variadas formas de 
ocupações e de protestos (occupy.net). Essa força do movimento se deve à rápida difusão de um ativismo on-line que intervém no fulcro do funcionamento social constituindo um tipo novo de participação. E mostra que a chamada "crise da representação" não se limita a uma crise dos partidos e da política. Trata-se antes de uma crise mais ampla, que atinge também o campo do discurso e das instituições tradicionais em que o sujeito se constitui.

No caso do Occupy, como em outros, os protestos evidenciaram — ou criaram - um vazio das ideologias correntes. A urgência de mudança, de imposição de um basta à nossa civilização desregrada, e em especial a revolta dos mais jovens contra quem quer que porte uma bandeira institucional, ou represente algum tipo de autoridade - a polícia, os partidos, os governos, mas também as grandes corporações e até a imprensa - demonstraram em ato o fracasso das soluções pragmáticas usuais. E após décadas de repetição incessante de análises socioeconômicas liberais, algumas centenas de jovens acampados puseram novamente a força crítica do mundo em ação, em confronto com os problemas mais estruturais da nossa civilização.

Em momentos extremos como estes, algo do recalque que a cultura vigente institui cede, revelando a Outra cena que perpassa a nossa formação social. Daí por diante, podemos dizer com Freud, o problema estará deslocado. Não conseguiremos mais lidar com as dificuldades da democracia e do capitalismo ignorando o fato de que o que opera na vida social não é apenas uma economia financeira e política, mas também o sujeito impulsionado pela ordem pulsional (FREUD, 1921 e 1932/1996). Uma ordem que é efeito do discurso, e da dependência do sujeito à estrutura da linguagem. E que articula os interesses e apetites humanos não à necessidade, mas a uma economia de gozo - que implica a economia psíquica associada a uma economia do capital, na produção de um laço social determinado (LACAN, 1968-9/2008; COSTA-MOURA \& FERNANDES, 2011).

Dizendo de outro modo, e segundo a experiência da psicanálise, desde que o laço capitalista transforma a perda implicada na civilização — ou, nos termos de Lacan (1968-9/2008), a renúncia ao gozo que é correlata do advento do sujeito no campo da linguagem — - em expropriação da atividade humana, ${ }^{4}$ sob a forma da mais-valia, emerge para o sujeito, uma marca de expropriação que liga o sujeito aos objetos, como objetos (de um gozo) a recuperar. É essa economia pulsional que impede, em última instância, que uma regulação meramente econômica possa operar a limitação de interesses necessária para a vida em sociedade. Mais ainda, impossibilita que uma transformação deste estado de coisas possa sobrevir imediatamente de uma ação global, revolucionária,

\footnotetext{
${ }^{4}$ Em estudo anterior, trabalhamos a demonstração de Lacan de que a perda que é efeito da constituição do sujeito na linguagem se mostra no capitalismo sob a forma da mais-valia. (LACAN, 1968-9/2008; COSTA-MOURA \& FERNANDES, 2011).
} 
como se sonhou durante décadas. Depois de Freud, é difícil aderir à aspiração de Marx de que uma transformação da ordem econômica possa ter um efeito regulador do capitalismo. O testemunho da psicanálise é, ao contrário, o de que o passo em direção à limitação do gozo — de cada um, bem como aquele da vida social — é um passo ético, cujo ordenamento não se faz por comando (a força das catracas), mas tampouco, a rigor, se faz com o 'passe livre'. Exigindo antes um posicionamento que, no caso da vida social, tem que ser conquistado nas lutas políticas específicas que podem chegar a impor perdas determinadas a cada vez (COSTA-MOURA \& FERNANDES, 2011).

A apostar na perspectiva psicanalítica, portanto, o desfecho destas situações está em aberto. E a prova mais dura para a nossa cultura e nossa ordem social hoje diz respeito a poder tomar lugar nas questões que permanecem, para além da irrupção momentânea das massas nas ruas. E poder aceder ao que, nesta irrupção, se articulou como um real que excede as intenções - e nos atinge a todos. Assim, a interpretação do que está em jogo nos protestos não é apenas um problema epistemológico - a débâcle da sociedade, da imprensa e dos analistas teóricos sobre qual seria a verdadeira mensagem da "voz das ruas" - e nem mesmo meramente político. Há aí também, como já dissemos com base na experiência psicanalítica, uma questão ética, que diz respeito ao destino que daremos a esse real que vigora no epicentro destes movimentos. Um real — assim o propomos - que está articulado à sua forma de interlocução e agenciamento.

\section{'\#HASHTAGS', 'PERFIS' E OUTROS 'MEMES'}

Foi nas redes sociais que o evento "Terceiro grande ato contra o aumento da passagem” marcado para São Paulo, capital, se 'viralizou': 28 mil pessoas confirmadas. Aliás, pessoas não, perfis — porque se, juridicamente se associa umas aos outros, sua correlação no real não é tão simples.

Um Perfil é um modo específico de tomar lugar e participar da vida social. Entre os 28 mil confirmados, obviamente, havia inúmeros perfis de outros estados e mesmo de outros continentes, pois em se tratando de um acontecimento que se articula na rede essa possibilidade se abre: posso não ir, mas confirmo presença para declarar apoio. O chamado 'evento' do Facebook por sua vez vale como uma espécie de mural embutido na interface. Nascido dos fóruns de discussão que aglutinaram comunidades inteiras na rede desde 1979, quando a web veio a público, mas diferente das antigas 'comunidades' (do Orkut, por exemplo), os "Eventos" do Facebook têm como horizonte o desaparecimento. Um 'evento' acontece. E uma vez 'pertencente' a ele, o 'perfil' pode publicar conteúdo multimídia de todo tipo, endereçado instantaneamente a todos aqueles associados ao 
evento. Vale para uma festinha (uma 'social') de adolescentes ou uma passeata com um milhão de pessoas nas ruas, parando o país.

Já um 'meme' de internet é um conceito, uma ideia ou mesmo um estilo que se propaga rápida e intensamente pela www, sob a forma de hiperlink, vídeo, imagem, website, hashtag, etc., podendo se espalhar de pessoa para pessoa através das redes sociais, blogs, e-mails, fontes de notícias e outros serviços baseados na web, tornando-se em geral o que se costuma adjetivar como "viral" — de onde também se extrai o verbo "viralizar" que empregamos aqui e que é muito utilizado neste contexto para designar a propagação e, em especial, o momento de virada em que uma unidade de informação adquire a capacidade de se transmitir de forma vertiginosa.

Nas manifestações recentes o 'evento’ tem funcionado como uma espécie de Ágora contemporânea, um espaço em que vão se depositando narrativas multifacetadas das lutas e acontecimentos menores - com possibilidade de serem curtidas (apoiadas), seguidas (valorizadas em termos de popularidade), comentadas (até o ponto de serem discutidas e virarem polêmicas no espaço público) e, a mais reiterada das ações na rede, compartilhadas (difundidas pelos perfis). Essa é justamente a potência mais específica das hashtags.

Uma hashtag é uma palavra ou uma frase prefixada, precedida pelo símbolo \# (hash, em inglês). Na verdade, e mais radicalmente, qualquer combinação - mesmo aleatória — de letras ou caracteres liderados pelo símbolo \# é uma hashtag, porque se trata justamente de uma formalização da linguagem de tal ordem que nenhuma semântica vem caracterizá-la como linguagem. Um 'post' qualquer, em mensagens curtas de microblogging e serviços de redes sociais como o Twitter, Tumblr, Instagram, Flickr, Google + ou Facebook pode ser marcado com um ou inúmeros — o número é ilimitado — “\#” antes de palavras ${ }^{5}$ que passam a fornecer um meio de agrupamento instantâneo de mensagens e metadados os quais, a partir daí podem ser acessados, ao alcance de um clique, de qualquer lugar do planeta, juntamente com o conjunto todo (streamming) de mensagens que circulam na rede com a mesma \#.

As hashtags são usadas ainda para marcar mensagens individuais como pertencente a um grupo específico, ou marcar as mensagens como relevantes para determinados tópicos ou assuntos. Funcionam também como balizas para que os usuários encontrem e sigam (se filiem à cadeia) ou articulem listas de contatos ou apoios públicos com outros usuários de interesses semelhantes. Além disso, aparecem de modo informal, apenas para expressar algo em uma mensagem

\footnotetext{
${ }^{5}$ Mais exatamente as \#hashtags podem ser inseridas em qualquer lugar de uma mensagem: antes do corpo de texto, foto ou vídeo que constitui um 'post'; fazendo parte do corpo de um 'post' (como em "Este é um \#protesto que aconteceu na Ave. Paulista”) ou ao final do corpo de um 'post'.
} 
(como um contexto, por exemplo), sem nenhuma intenção de categorizá-la para busca posterior ou compartilhamento. Uma \# pode ajudar a expressar humor, tristeza emoção, ou dar outras pistas contextuais, como por exemplo, \#fofo, \#sarcasmo, \#partiu (\#partiu festa, \#partiu praia, etc.), \#love (utilizada mais de 500 milhões de vezes só no Instagram) ou\#me (200 milhões no Instagram — ambos, segundo http://web.stagram.com/).

A importância das hashtags cresceu com a ascensão e popularidade do Twitter. Mas elas se tornaram instrumento político durante os protestos relacionados às eleições iranianas de 2009-2010, como meio de identificar e classificar os assuntos dos posts e conectando (por meio das palavrinhas estanques e facilmente identificáveis) internautas dentro e fora do Irã, de modo a contornar a dificuldade da língua. No Tweeter, onde surgiram, elas eram utilizadas em frases ou palavras para interligar assuntos ou vários posts sobre um mesmo assunto - e acabaram se tornando essenciais para a indexação de conversações por temas e palavras (o sistema tendo sido por fim adotado por várias outras redes sociais como Instagram e Facebook). Com o tempo, mas em velocidade recorde, as hashtags se tornaram verdadeiros fóruns de discussão ad hoc, não moderados, globais e horizontalizados. Qualquer hashtag, se promovida por número suficiente de posts pode virar 'tendência' e atrair mais usuários para discussão em torno do tópico proposto.

A partir de 2009, o Twitter começou a conectar em 'hyperlink' todas as hashtags nos tweets do Twitter. Introduzindo a seguir (2010) um sistema de contagem e levantamento de frequências que permite identificar os "Trending Topics" (ou seja, aqueles tópicos que estão sendo mais discutidos, seguidos, republicados, aqueles que formam uma 'tendência') na primeira página do Twitter (ou na barra de pesquisa no cabeçalho de um site de rede social). Hoje existem várias empresas fornecedoras de serviços (em sua maioria consumidos por outras empresas) de “Tagboard" — ou seja, de medição e monitoração dos movimentos dos posts ou de avaliação específica, as quais dispõem em termos visuais a distribuição gráfico-temporal para hashtags utilizadas em sites de mídia social.

Toda essa dinâmica das redes sociais ilustra a forma intrigante de relação dos jovens com o espaço público (CASTRO, 2004, 2013) — em termos da articulação 'rua e rede' que emerge na contemporaneidade. Nas convocações para os eventos, por exemplo, há aqueles que estão presentes na rua e há os que estão na rede. Ambos 'postando', ambos dentro da mobilização - e da rede. Os primeiros, relatando, fotografando enquanto os outros (alguns, certamente, do sofá, sem que seu papel seja menos fundamental por causa disso) espalham, convocam, incitam e comovem. A internet sendo ocupada tanto pelos "confirmados e presentes na rua" quanto pelos "confirmados e presentes na rede".

Mas o que essa sucessão (sem substituição, segundo apontam Freitas \& Costa, 2005) da oralidade, da escrita e da informática, como modos fundamentais do 
discurso aporta de complexificação e deslocamentos de centros de gravidade, para o advento do jovem no laço social? O que estrutura esse laço discursivo que emergiu com toda força na atualidade e cujas incidências apenas começamos a interrogar? Que lugar reserva ao sujeito? Certamente não o centro. Quando um 'evento' ou 'fórum' ou 'post' ou 'perfil' viraliza, isto implica que aquela unidade de informação adquiriu a capacidade de se reproduzir de forma autônoma, o "streaming" se espalhando com força e velocidade exponenciais. Neste ponto acontecem tentativas de stalkear (quebrar o código, "tomar a administração de") uma dada página, ou post, e/ou tentar identificar quem são "os líderes”, quem teria convocado o movimento. Em geral, tarde demais, pois quando o número de posts e tweets explode, não há mais um centro, e sim, milhares.

Essa é justamente a condição que distingue o sujeito que emerge com a ciência moderna. Para o sujeito que habita o universo infinito no qual a ciência transmutou, o mundo fechado do Cosmos antigo (KOYRÉ, 1962/1998), o centro está em toda parte e a circunferência em nenhuma. E no caso da contemporaneidade, disseminada numa infinidade de máquinas pelo mundo, que formam, segundo Mathias (2010), uma nebulosa informacional insondável. Uma dimensão na qual não há mais lugar para lideranças e comandos centrais, retilíneos; só há lugar para a chamada emoção n-1 (MALINI, 2013), ou seja, a ligação que deriva de um efeito dos nós da rede (n) que atravessam o perfil (1).

E os canais n-1 / 1-n (este último designando um post que emana de um perfil e ganha a rede) não se reduzem a nenhum ponto fixo: todos podem ser em algum momento a fonte primária de notícias. Quando alguém republica um (post de um) perfil x (@fulano de tal), cria-se uma relação determinada com a rede. Quando muitos outros fazem a mesma operação, o perfil x (@fulano de tal) ganha uma dimensão a mais (o ponto vira traço, por exemplo), uma posição especial na rede. A chamada 'centralidade de autovetor' é um modo de compreender a posição de um perfil e sua relação com outros espaços da rede. Na prática, se um tweet 'postado' por um perfil é muito republicado, o perfil ficará próximo a perfis jornalísticos, políticos, empresariais, governamentais, de celebridades e outros. Um post pode ganhar centralidade tenha ele vindo de um governante poderoso (@barackobama),uma corporação global (@ cocacola) ou de um ‘@fulano' qualquer; a força que cria a posição do perfil não deriva de um desejo do perfil, nem apenas de sua visibilidade, mas sobretudo de como este é apropriado pela rede. Para Malini (2013) “É o outro que cria a perspectiva. Quanto mais relações com outras subredes, mais 'centralidade de autovetor' possui um dado perfil, ou seja, mais força é atraída por ele”. Central, portanto, é aquele perfil que consegue atrair uma intensidade multiplicadora de relações - e isto muito para além do que alguém poderia deliberar, ou controlar (o que explica também porque um perfil não coincide com uma pessoa). 
Observemos ainda que nessa nebulosa de linguagens transitórias, não apenas se lê ou se escreve — no sentido usual destes termos, que os relaciona a decodificar: letras, palavras, sentidos, estruturas. Trata-se antes de sermos tomados nesse laço, por assim dizer, envolvidos pelas múltiplas afetações possíveis. Como 'usuários da rede', somos antes de mais nada o efeito engendrado nessa prática de "postar" que pode ser infinitizada.

\section{LÓGICA DA CIÊNCIA, DISCURSO E REPRESENTAÇÃO DO SUJEITO}

É conhecido o fato de que a operação científica implica a substituição da linguagem ordinária pela linguagem formal. Mas mais do que isso, sabemos hoje - graças ao trabalho de autores clássicos como Koyré e Kuhn (1962 e 1970) e também contemporâneos como Latour (1998) e Boltanski (2012), entre outros - que esta substituição acarreta uma transformação radical da nossa relação com a linguagem. E com Lacan (1965-6/1998), que este remanejamento do campo discursivo porta inúmeras consequências para o sujeito.

Lacan (1969-70/1991) mostra como a ciência demarca significantes que se organizam, que respondem a leis, sem estarem relacionados a um sujeito ou a uma essência que se expressaria por seu intermédio. A partir da ciência, o campo discursivo pode não ser mais o do significante - onde subsiste a presença do Outro, na forma do mistério da significação, do enigma, por exemplo, ou da metáfora - , e sim o da literalização, no qual pequenas letras intercambiáveis valem, e são definidas exclusivamente a partir da ordem de suas comutações. A formalização da linguagem que está na base da ciência produz esse esvaziamento da potência do significante para produzir equivocação, com a consequente dissolução dos laços articulados pelas diversas culturas que ligavam os significantes a determinados campos semânticos. E no roldão dessa degeneração (e virtual supressão) da diferença significante que poderia causar um sujeito a advir, o significante, tornado pura sintaxe, se condensa em letra. Ganhando valência real, vale dizer: sua incidência torna-se compulsória, seu encadeamento, automático, prescindindo do sujeito para sustentar-se.

Em trabalhos anteriores pudemos discernir como a neutralização da dimensão significante — que engendra a equivocidade da linguagem — pela formalização, problematiza a sustentação do lugar do sujeito no campo do discurso que estrutura o laço social (FERNANDES \& COSTA-MOURA, 2009, 2010). Nesta direção argumentamos que a manobra formal de esvaziamento da dimensão significante está na base de quase todos os aspectos que regulam nossa vida cotidiana (tais como a numerização dos nossos dados, aferição de nosso saldo no banco, de nossas medições sanguíneas, etc.), e mais ainda, que esta ambição 
de superar o significante compõe o modo de funcionamento do discurso que constitui a tessitura mais fundamental do laço social contemporâneo.

A sustentação da vida social na dimensão formal da diferença (binária, previsível) dos traços, números e outras cadeias exclusivamente sintáticas substitui o laço discursivo que daria lugar ao sujeito, na contemporaneidade, com a consequência exorbitante de propiciar um controle estrito, instantâneo e contínuo de toda a gama de efeitos de linguagem que suscitariam o sujeito a advir. Mas não se trata apenas da possibilidade de inserir os indivíduos no nó econômico, técnico, científico de controle e vigilância. Dessa expropriação, como dissemos, do que teria sido seu lugar simbólico, emerge um sujeito extirpado de essência e substância. Um sujeito inteiramente apenso a este estatuto contingente dos discursos que é efeito da introdução, pela ciência moderna, do significante reduzido à radicalidade de seu jogo diferencial, como letra.

Este sujeito não pode mais dispor do saber imediato que emanaria de um mundo bem ordenado. Restando-lhe a possibilidade (e o encargo) de ordenar o mundo ele mesmo. Porém, quando a marcha da ciência substitui a ordem significante pela precisão de um saber matemático, quanto mais o sujeito procura obter uma identidade, menos ele encontra um significante que possa vir a representá-lo frente ao Outro, aos outros e à vida social. Recaindo no limite, sobre o ato de asserção e afirmação de uma certeza que não pode ser senão antecipada (DESCARTES, 1641/2001; LACAN, 1945/1998, 1965-6/1998, 1967-8), o único esteio no qual um sujeito pode se fundar. Doravante, no que concerne ao sujeito que emerge com a ciência, se penso, logo existo (mas, e se eu não penso - como mostrou Freud - e algo pensa em meu lugar?). Tendo que se fazer representar pela letra que é cifrada, é o sujeito quem vacila, como resultante. Tornando-se, no limite, uma subsistência pontual, cuja substância além de ser circunscrita a cada momento pelas determinações econômicas e sociais, é dependente da efetivação de um laço discursivo que possa testemunhar, aqui e ali, sua presença sintomática no real.

Entretanto, na contemporaneidade, o que se produz em lugar dessa ordem discursiva que poderia ensejar um sujeito a vir se responsabilizar pelo desejo que o constitui e o enlaça na vida social, é um comparecimento do sujeito adstrito à esfera irresponsável do consumo. Esse sujeito articulado ao consumo é o que é promovido exaustivamente pelo capitalismo e instrumentalizado pela ciência. No limite se trata de uma exacerbação do que já está em jogo na própria dinâmica pulsional; um acossamento que erode, por outro lado, inevitavelmente, os outros canais institucionalizados de representação do sujeito — até o ponto inusitado de praticamente confinar esta representação às selfies, e posts do Facebook, que não chegam a suportar uma inclusão mais decisiva do sujeito, no laço social. 
Para os jovens, então, esse problema da representação é candente. São eles que experimentam de maneira mais radical hoje, que a internet, muito mais que um instrumento de comunicação que conecta emissores à distância (como seria o caso do telefone, ou dos correios) se apresenta para nós como um "fenômeno total" (MATHIAS, 2010) ou totalizante; uma extensão cada vez real e opaca de nossa vida, de suas exigências e mesmo, de seu sentido. Quando um jovem, ou milhões, se engajam no discurso digital que se materializa na internet, que laço se produz? A rigor estamos impossibilitados de saber a contento. Como já mencionamos aqui, a experiência de cada um com a rede está circunscrita a programas e aplicativos dos quais somos menos que usuários; somos efeitos. Efeitos de um laço discursivo formal no qual ingressamos, e que nos permite certas operações - virtualmente infinitas por um lado, mas não obstante coadunadas a um número restrito de gestos calculados, previstos e uniformes. Executamos estes gestos o tempo todo sem ter a menor ideia do que implicam as leis de sua formação, ou dos protocolos informáticos que utilizam em sua configuração. É importante observar no entanto que não é apenas o espaço virtual e a internet que estão em questão quando se trata destes novos expedientes de encadeamento discursivo que circulam entre os (cada vez mais) jovens e fazem a rede. Trata-se para cada um de nós, de nada menos do que o modo como tomamos a palavra e nos responsabilizamos pela vida e pelo laço social. Trata-se da ordem do discurso, como aquela que pode dar lugar ao sujeito (LACAN, 1971/2009).

\section{PROLIFERAÇÃO DAS \#HASHTAGS}

Ainda que determine o sujeito, a ordem do discurso não lhe pertence e nem o toma por referência. A ordem do discurso responde às leis da linguagem - à diferenciação de lugares e circulação de elementos determinados por estas leis, em sua incidência que é estrutural e constitui todo o domínio humano. Para a psicanálise um sujeito é produto da articulação significante elementar que também engendra o discurso, mas não obstante, vale ressaltar, "o sujeito como tal nunca domina essa articulação” (LACAN, 1971/2009, p.18). Como o discurso se funda na estrutura (LACAN, 1971/2009, p.10), ele não pode ser o discurso de um particular (genitivo subjetivo). E por isso também ele não comporta o exterior a partir do qual se poderia julgá-lo. A própria ordem do discurso "exclui a possibilidade de [...] abarcar tudo" (LACAN, 1971/2009, p.12), de dizer inteiramente. Não há, pois, metalinguagem que possa avaliar o discurso. E não há tampouco, em nenhuma parte, um universo do discurso (LACAN, 1968-9/2008) — nenhum "discurso universal”, que valha por todos. Todo discurso tem condições e é mesmo idêntico às suas condições. E como o discurso não faz Um; o(s) discurso(s) circula(m) continuamente. Lacan (1969-70/1991) isolou quatro; 
nenhum se impõe o tempo todo, nenhum dura a ponto de suprimir por inteiro os outros. Se a marcha da ciência explodiu o Cosmos como mundo fechado, onde cada coisa e cada um tem seu lugar, o sujeito, em consequência, em lugar de (re)encontrar sua casa no Universo infinito está constrangido necessariamente a ordenar o mundo e se determinar a cada vez pela via do discurso - que não cessa, que circula, que prolifera e condena o sujeito a habitar aquilo que Lacan designou como um “desuniverso" (LACAN, 1971/2009, p.12).

Deixando de lado a pretensão de explicar e de compreender, se nos ativermos, à maneira de Barthes (1971[1984]/1988), a fazer "levantamentos de discurso" encontraremos talvez na multiplicação das \#hashtags convocando e suportando tantos movimentos sociais contemporâneos, este habitante de um desuniverso do discurso criado pela tecnociência; e a própria prática linguageira dos jovens na web configurando um modo de inserção que não se detém em analisar, discutir, decodificar a vida social, e sim de sobrecodificar, produzir, multiplicar, amontoar linguagens. E deixar-se atravessar por elas. Contra um capitalismo que se globalizou baseado em estruturas verticais e hierarquizadas, eis que surgem movimentos que propõem e praticam formas de redes descentralizadas (CASTELLS, 2012), rizomáticas (DELEUZE \& GUATARRI, 1980); sem personificação de lideranças nem comando de partidos. Em lugar de uma única explosão, ações locais, temporárias, experiências concretas de reapropriação do espaço urbano e organização de outra experiência cotidiana da metrópole — numa luta que tem a dimensão do mundo.

Vista por este prisma, a negatividade e a indefinição política do modo espontâneo de manifestação que brotou em nossas cidades são sua positividade como movimento. São sua ação. A presença maciça de jovens nas ruas que estes movimentos articulam realiza por si só uma reversão do que seria uma negatividade (falta de uma pauta consistente de reivindicações, de direção, de programa político, etc.), em positividade. A positividade que faz da negação (do que está posto, determinado pela máquina que reproduz o status quo), uma onda; uma força que atinge o próprio campo do discurso - evidenciando a força de causa que perpassa o significante, concentrada em tags.

Decerto as propostas alternativas ao modelo dominante que apenas começam a se esboçar no bojo destes movimentos, precisarão ainda ter seu tempo de experimentação e de formulação. Mas ao que tudo indica, provavelmente, como conclama o Movimento Passe Livre, "não começou em Salvador e não vai terminar em São Paulo” (MPL/SP, 2013, p.13). 


\section{REFERÊNCIAS}

ALI, T. (2011) O espirito da época, in HARVEY, D. et al. , Occupy. São Paulo: Boitempo.

BARTHES, R. (1971[1984]) Da obra ao texto, in O rumor da língua. São Paulo: Brasiliense.

BOLTANSKI, L. (2012) Énigmes et complots: une enquête à propôs d'enquêtes. Paris: Gallimard.

CASTELLS, M. (2012). Redes de indignação e esperança . Rio de Janeiro: Jorge Zahar.

CASTRO, L. R. (2004) Circulando pela cidade:trajetos e projetos; diversão e conversão, in _. A aventura urbana: crianças e jovens no Rio de Janeiro. Rio de Janeiro: 7Letras.

. (2013). A aventura da ação e a participação das crianças na cidade, in _. O futuro da infância e outros escritos. Rio de Janeiro: 7Letras.

COSTA-MOURA, F. \& FERNANDES, F. L. (2011). A psicanálise existe? Considerações sobre o materialismo da psicanálise, in LO BIANCO, A. C. (Org.) A materialidade da psicanálise. Rio de Janeiro: Contra Capa.

DELEUZE, G. \& GUATTARI, F. (1980) Mille Plateaux: capitalisme et schizophrénie. Paris: Minuit.

DESCARTES, R. (1641/2001) Discurso do método. São Paulo: Martins Fontes. FERNANDES, F. \& COSTA-MOURA, F. (2009) Lógica da ciência, formalismo e forclusão do sujeito, in COSTA-MOURA, F. (Org.) Psicanálise e laço social. Rio de Janeiro: 7Letras.

\& (2010). Quem sabia? O escrito como fundamento do real, in OLIVEIRA, C. (Org.) Filosofia, psicanálise e sociedade. Rio de Janeiro: Beco do Azougue.

FREITAS, M. \& COSTA, S. R. (Orgs.) (2005) Leitura e escrita de adolescentes na internet e na escola. Belo Horizonte: Autêntica.

FREUD, S. (1996). Edição standard brasileira das obras psicológicas completas. Rio de Janeiro: Imago.

(1921) "Psicologia de grupo e análise do ego", v.XVIII, p.81-154.

(1932). "Novas conferências introdutórias sobre psicanálise. XXXV: a questão de uma Weltanschauung, v.XXII, p.155-177.

KOYRÉ, A. (1962/1998) Du monde clos à l'univers infini. Paris: Gallimard.

KUHN, T. (1970/1998). A estrutura das revoluções científicas. São Paulo: Perspectiva.

LATOUR, B. (1998/2011) Ciência em ação: como seguir cientistas e engenheiros sociedade afora. São Paulo: Unesp.

LACAN, J. (1945/1998) O tempo lógico ou a asserção de certeza antecipada: um novo sofisma, in Escritos. Rio de Janeiro: Jorge Zahar. (1965-6/1998) A ciência e a verdade, in Escritos. Rio de Janeiro: Jorge Zahar.

. (1967-8) L’acte psychanalytique. Seminário inédito.

(1968-9/2008). O seminário livro 16: de um Outro ao outro. Rio de Janeiro: Jorge Zahar.

(1969-70/1991). Le séminaire livre XVII : l'envers de la psychanalyse. Paris: Seuil. 
(1971/2009). O seminário livro 18: de um discurso que não fosse semblante. Rio de Janeiro: Jorge Zahar.

MALINI, F. (2013) A Batalha do Vinagre: por que o \#protestoSP não teve uma, mas muitas hashtags. Disponível em: http://www.labic. net/cartografia-das-controversias/a-batalha-do-vinagre-por-que-o-protestosp-nao-teve-uma-mas-muitas-hashtags/

MOVIMENTO PASSE LIVRE — SP (2013) Não começou em Salvador e não vai terminar em São Paulo, in MARICATO, E. et al.. Cidades rebeldes: Passe Livre e as manifestações que tomaram as ruas do Brasil. São Paulo: Boitempo. MATHIAS, P. (2010). Qu'est-ce que l'Internet ? Paris: Vrin.

SAFATLE, V. (2011) Amar uma ideia, in HARVEY, D. et al., Occupy. São Paulo: Boitempo.

SAKAMOTO, L. (2013) Em São Paulo o Facebook e o Twitter foram às ruas. In. MARICATO, E. et al.Cidades rebeldes: Passe Livre e as manifestações que tomaram as ruas do Brasil. São Paulo: Boitempo.

ZIZEK, S. (2011) O violento silêncio de um novo começo, in HARVEY, D. et al., Occupy. São Paulo: Boitempo.

(2013) Problemas no paraíso In. MARICATO, E. et al.. Cidades rebeldes: Passe Livre e as manifestações que tomaram as ruas do Brasil. São Paulo: Boitempo.

\section{Sites consultados}

http://web.stagram.com/hot

http://web.occupywallst.org

http://web.occupy.net

Fernanda Costa-Moura

fcostamoura@infolink.com.br 